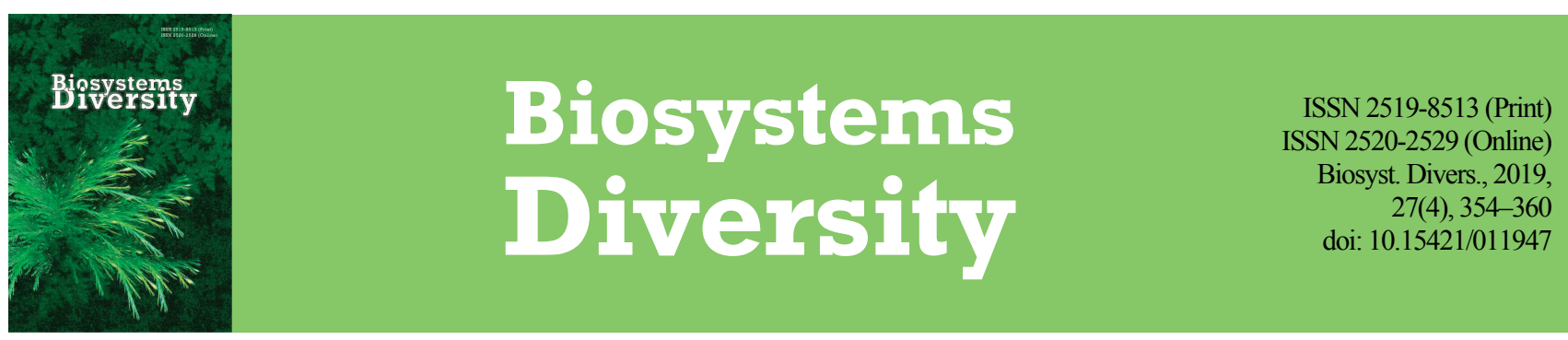

\title{
Population density and structure of birds breeding in an urban habitat dominated by large baobabs (Adansonia digitata), Northern Namibia
}

\author{
G. Kopij \\ University of Namibia, Oshakati, Namibia
}

Article info

Received 07.10.2019

Received in revised form 11.11.2019

Accepted 12.11.2019

University of Namibia, Private Bag 5520,

Oshakati, Namibia.

E-mail:g.kopij@unam.na

\begin{abstract}
Kopij, G. (2019). Population density and structure of birds breeding in an urban habitat dominated by large baobabs (Adansonia digitata), Northern Namibia. Biosystems Diversity, 27(4), 354-360. doi:10.15421/011947

Large baobabs are regarded as key plant species in the savannah biome. In this study their role in shaping the avian community has been evaluated. The territory mapping method has been employed to quantify the avian breeding community in the town Outapi (ca. 130 ha), Northern Namibia, well-endowed with large baobabs. A total of 29 breeding bird species were recorded. The alien House Sparrow was by far the most numerous species comprising $48.4 \%$ of all breeding birds. The Blue Waxbill and African Palm Swift were also classified as dominant species, comprising together $17.4 \%$. Granivores were by far the most numerous feeding guild, comprising $77.2 \%$ of all birds breeding, while the insectivores comprised only $11.8 \%$. Birds nesting in/on buildings comprised $52.7 \%$, those nesting on trees/shrubs $-42.0 \%$. The population densities of many bird species (e.g. doves from the genus Stepropelia, bulbuls, weavers) were comparatively low. Such a situation could have been caused by the exceptionally high population density of the Pied Crow. In the study area, there were 15 breeding pairs and about 100-150 non-breeding individuals. The baobabs may provide them with a feeding resource in the form of the sweet fruits. The crows, as nest predators, feed also on the eggs and nestlings of other birds. Doves seem to be especially prone to such predation, as their nests are easily to detect and destroy. As a result, they have to breed in low density. This in turn, may release other dominant granivores in the study area, namely sparrows. They are not vulnerable to crow nest predation, as their nests are usually well-concealed under eaves and in holes of buildings.
\end{abstract}

Keywords: associations; community ecology; Corvus albus; Passer domesticus; Streptopelia doves.

\section{Introduction}

The urbanized environment can be considered as an arena of conflicting relationships between human and birds. Thus, town hygiene may face a problem of nesting pigeons and sparrows, historical buildings and monuments may be corroded by bird guano, colonially nesting herons and egrets may pollute urban water reservoirs. On the other hand, birds may play a positive role in towns. The insectivorous birds protect greenery from pests, and they eliminate disease-bearring insects such as mosquitoes (Culicidae), biting midges (Ceratopongidae), black flies (Simulidae), horse flies (Tabanidae) house flies (Muscidae) and many others. They also bring back to the towns and cities life, splendour and beauty, so important in the development of human integrity and spiritual harmony. They therefore sustain and reinforce moral values of urban societies.

For the last few decades, birds breeding in towns and cities have become a subject of thorough investigation in some countries in the northern hemisphere (Chace \& Walsh, 2006; Dunn \& Weston, 2008; Magle et al., 2012; Luniak, 2013, 2017). This investigation has enormously contributed to nature conservation, as contrary to expectation, some bird species may flourish in urbanized habitats (Kopij, 2001, 2015a, 2014a, 2016, 2018a, 2018b, 2018c; Dunn \& Weston, 2008). They may find in urbanized habitats abundant food resources and suitable nesting sites, lack of predators, and a sort of protection against adverse weather conditions.

Interesting aspects of avian ecology and behaviour can also be easily tested in urbanized habitats, for example urbanization mechanisms, behavioural and ecological adaptations, urbanization gradients, population dynamics, etc. (Crooks et al., 2006). Recently, longitudinal changes were detected in proportions of some bird species breeding in towns of Northern Namibia (Kopij, 2014a). The major factor responsible for these changes is the differential precipitation, with a gradual increase in rainfall from the west to the east. However, other factors, such as vegetation composition and tree cover or neighbouring vegetation may also play a role in this regard. Most Namibian towns were established quite recently, therefore monitoring avian populations there may reveal interesting adaptations and modifications in birds.

In this study a more accurate method was employed to assess population densities and community structure of birds breeding in an urban habitat in this region. This habitat is well-endowed with trees and shrubs and receives relatively high annual rainfall. But the most conspicuous elements of this habitat are huge baobabs. They are well known to play a key ecological role wherever they grow (Gebauer et al., 2002; Sidibe \& Williams, 2002). It has been assumed that they may play a key role also in urbanized ecosystems, shaping, for example, the structure of avian communities. This study was undertaken to test this premise.

\section{Materials and Methods}

The study area was situated in the town Outapi, Omusati Region, Northern Namibia (Ovamboland), at $17^{\circ} 31$ ' S longitude and $15^{\circ} 00^{\prime} \mathrm{E}$ latitude. It is located within the Cuvalai Drainage System, comprising a mixture of mopane and acacia savanna, and dominated by the distinctive makalani palm Hyphaena petersiana (Mendelsohn et al., 2009). The study area constitutes a central part of this town between the main highway, running from Ongwediva to Ruacana, and a water canal running from Ruacana Waterfall eastwards (Fig. 1). The study area covers ca. 130 ha.

The study area is a densely built-up residential area, mostly with modern detached houses with roofs covered with corrugated iron (Fig. 2). There are fruit trees around most of these houses and numerous indigenous trees such as baobab Adansonia digitalis, camel thorn Acacia erioloba, makalani palm, marula Sclerocarya birrea, forming in some places clumps or rows. Other trees/shrubs include scented-pod acacia 
Acacia nilotica, black-thorn acacia Acacia millifera, sickle-bush Dichrostachys cinerea, sycomore fig Ficus sycomorus, mopane Colophospermum mopane. In few places, there are also exotic tress, such as gum trees Eucalyptus spp., she oaks Casuarina spp., etc. There are 10 larger non-built up plots (altogether ca. 20 ha in surface area) covered mainly with grass and few short shrubs on the peripheries. In the wet season most of them are flooded (so called oshanas). There are also a number of newly constructed government buildings, shops, lodges, garages, schools, and there is a hospital in this area.

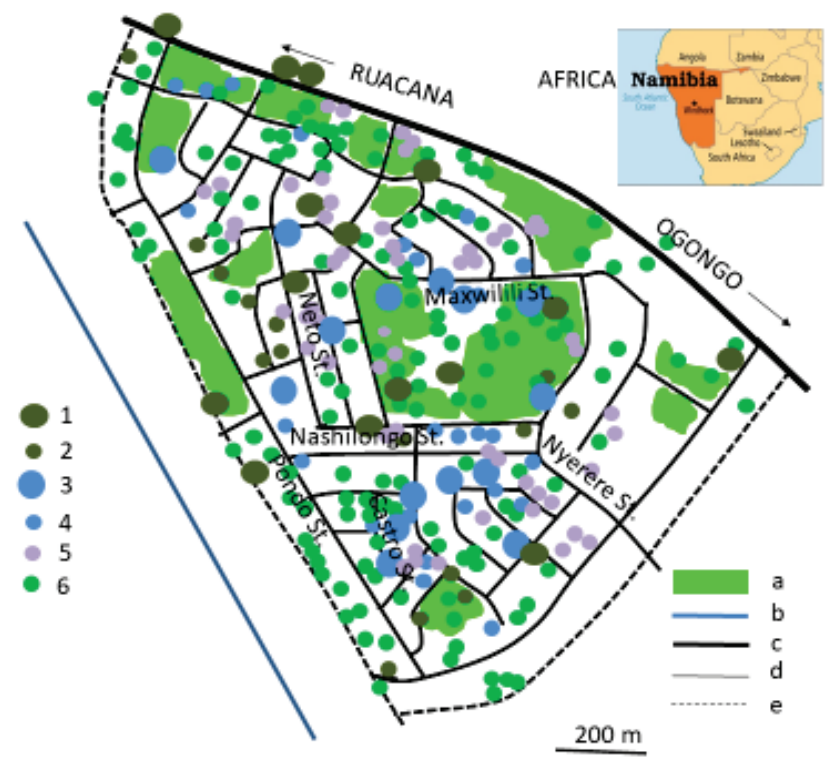

Fig. 1. The map of Outapi: $1-$ larger $(>2 \mathrm{~m} \mathrm{dbh})$ baobab, 2 - smaller baobab ( $<2 \mathrm{~m} \mathrm{dbh}), 3$ - larger marula $(>1.5 \mathrm{~m} \mathrm{dbh})$, 4 - smaller marula ( $<1.5 \mathrm{~m} \mathrm{dbh}), 5$ - fully grown makalani palm,

6 - other larger trees; $a$-open grassy spaces, $b$ - water canal, $c$ - highway, $d$-streets, $e$ - borders of the study area

The huge baobabs ( $>5 \mathrm{~m}$ in diameter at the breast height and about $20 \mathrm{~m}$ height) are prominent elements of Outapi (Fig. 2). Within the study area, there were 15 huge and 16 medium-sized specimens (2.0 $4.9 \mathrm{~m} \mathrm{dbh}$ ) of baobabs in 2017. There were also 15 larger (>1.5 m dbh) and 26 smaller $(1.5 \mathrm{~m} \mathrm{dbh})$ specimens of marulas and 56 fully grown makalani palm trees (own data). The marulas and makalani palms are also an important component of the urbanized habitat of inner Outapi, comprising a source of both food and nesting sites for birds.

Greater Outapi covers 1,008 ha. It was declared a town in 1997. In 2001, it was the smallest Namibian town with a population of 2600 , but 10 years later the population reached 6,437, and in 2017 it was estimated at 11,000 (Mwinga et al., 2018). There are 2,590 modern houses, 2,520 detached houses, and 70 apartments/flats; $23 \%$ of the population live in impoverished structures (shacks), and $12 \%$ in traditional houses. There are nine schools, each with spacious sport fields. There are $63 \mathrm{~km}$ of tarred roads, $190 \mathrm{~km}$ - gravel roads, and $160 \mathrm{~km}$ - earth roads within Greater Outapi. In 2017 there were 8,351 registered cars (Mwinga et al., 2018). The climate in Outapi is classified as semi-arid (Mendelsohn et al., 2009). The average annual temperature is $22.6^{\circ} \mathrm{C}$, while the variation in annual temperature is $8.7^{\circ} \mathrm{C}$ (Fig. 4). The average annual rainfall in Outapi is $441 \mathrm{~mm}$, with most of the rain $(\mathrm{x}=416 \mathrm{~mm})$ falling from November to March (https://en.climate-data.org/africa/namibia/omusatiregion/outapi-55824). Rainfall, however, varies markedly from year to year. For example, in the 2010/2011 wet season it was $723 \mathrm{~mm}$, 2015/2016 wet season $-330 \mathrm{~mm}$, while in the following 2016/2017 wet season it was $410 \mathrm{~mm}$ (Mwinga et al., 2018).

The territory mapping method has been employed (Bibby et al., 2012). Four counts were conducted over the whole study area: 1) 19 and 26 July, 2) 6 and 12 August, 3) 10 and 17 September and 4) 28 and 29 October 2017. All counts were conducted in the mornings. A bird/birds of the same species showing breeding or territorial behaviour recorded at least on two such surveys were assumed to be representing a breeding pair. Birds were counted while walking slowly along streets. The routes were designed to cover the whole study area. All birds showing breeding (e.g. transporting nesting material, constructing nests, feeding chicks etc.) or territorial (e.g. singing males) behaviour were plotted on a map. Special attention was paid to simultaneously singing males, as they were important in determining the number of occupied territories. Special attention was also paid to prevent double counting and overestimating the number of territories.

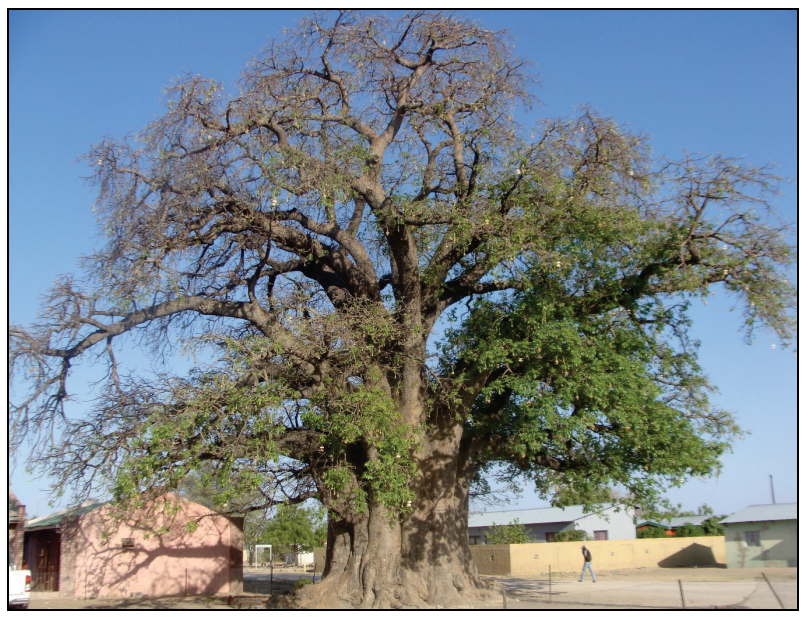

Fig. 2. A view of residential area in Outapi (Northern Namibia) with a huge baobab tree

Each occupied territory has been treated as one breeding pair. Such a simplistic approach could, however, underestimate the number of breeding females of some polygamous species, specifically the Southern Masked Weaver Ploceus velatus or the co-operatively breeding Red-faced Mousebirds Urocolis indicus. In the case of Feral Pigeons Columba livia, the number of breeding pairs has been estimated by halving the total number of recorded individuals.

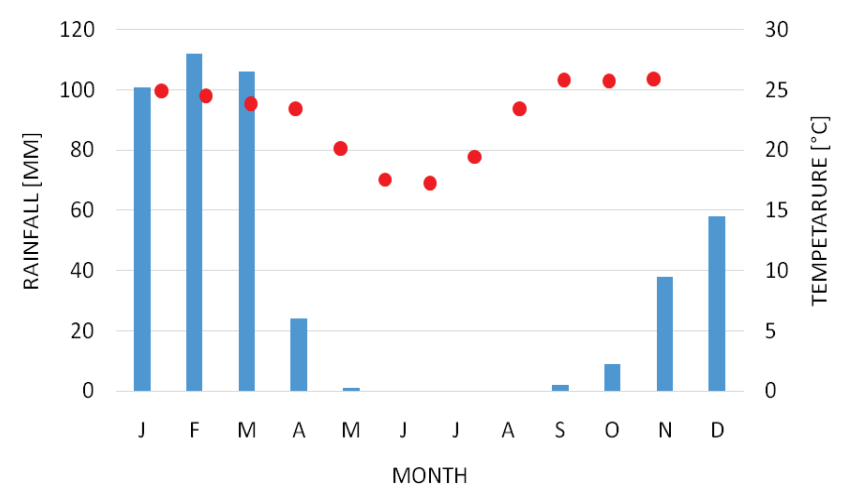

Fig. 3. Climatogram of Outapi (red dots - average monthly temperature, blue columns - average monthly rainfall)

The following guilds were distinguished:

- foraging: $\mathrm{G}$ - granivores; $\mathrm{I}$ - insectivores; $\mathrm{F}$ - frugivorous; $\mathrm{N}$ nectarivorous; $\mathrm{O}$ - omnivorous; $\mathrm{C}$ - carnivorous;

- nesting: $\mathrm{B}$ - on/in buildings; $\mathrm{G}$ - on the ground; $\mathrm{V}$ - in herbaceous vegetation; $\mathrm{T}$ - in trees or shrubs; $\mathrm{H}$ - in tree holes;

The following indices were used to characterize the diversity and evenness of the communities:

- Shannon's diversity index: $H^{\prime}=-\sum p_{i} \ln p_{i}$, where $p_{i}$ is the proportion of breeding pairs belonging to the ith species;

- Simpson's diversity index: $\mathrm{D}=\left(\left(\sum \mathrm{n}(\mathrm{n}-1)\right) / \mathrm{N}(\mathrm{N}-1)\right.$, where $\mathrm{n}$ - total number of breeding pairs belonging to a given species, $\mathrm{N}-$ total number of breeding pairs of all species;

- Pielou's evenness index: $J^{\prime}=\left(-\sum p_{i} \ln p_{i}\right) / \ln S$, where $p_{i}$ is the proportion of breeding pairs belonging to the ith species; $\mathrm{S}$ - total number of species. J' varies between 0 and 1 . The less variation between species in a community, the higher $\mathrm{J}^{\prime}$ is. 
- dominance index: $\mathrm{DI}=\left(\mathrm{n}_{1}+\mathrm{n}_{2}\right) / \mathrm{N}$, where $\mathrm{n}_{1}, \mathrm{n}_{2}-$ number of pairs of two most abundant species, $\mathrm{N}$ - total number of pairs of all species.

The dominance was calculated as the percentage of breeding pairs of a given species in relation to all breeding pairs of all species. A dominant species comprises $5.00-9.99 \%$ of all breeding pairs recorded, eudominant: $10 \%$ and more, while subdominant: $2.00-4.99 \%$. The nomenclature of English and Latin species names follows that in Hockey et al. (2005).
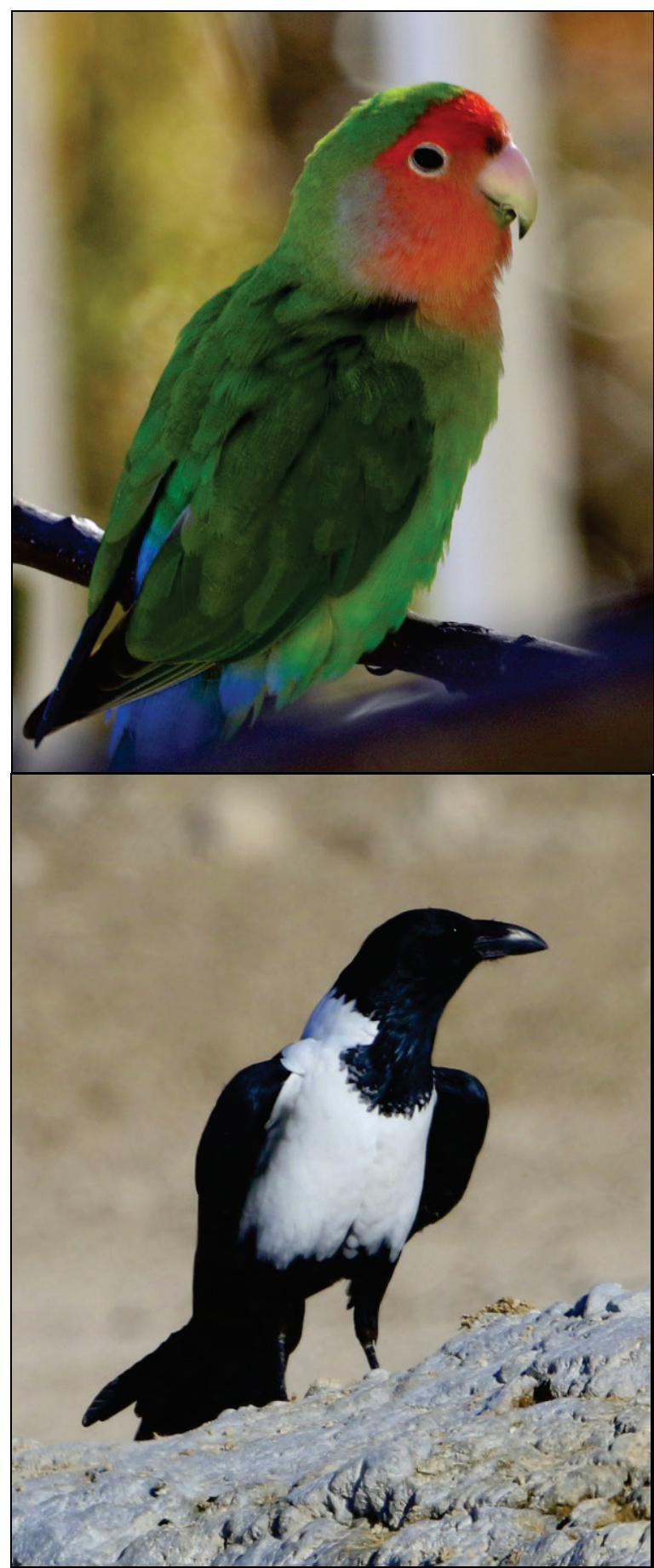

Fig. 4. From above, clockwise: Rosy-faced Parrot, Red-eyed Bulbul, Pied Crow, and Lilacbreasted Roller

The Blue Waxbill is a granivorous bird associated with thorny shrubs, while the African Palm Swift is an insectivorous species, strictly associated with the makalani palms, where it locates its nests. Although there were only three dominant species, the cumulative dominance and community dominance index were very high.

\section{Results}

A total of 29 bird species were recorded as breeding in the inner part of the town (Table 1). The House Sparrow Passer domesticus was by far the most numerous and eudominant species comprising almost half of all breeding pairs. It nested in a density of 192.3 pairs per 100 ha. The House Sparrow was strictly associated with small residential houses, where it nested mainly under the corrugated roofs. Two other dominant species, the Blue Waxbill Uraegnithus angolensis and African Palm Swift Cypsiurus parvus comprised together 17.4\% (Table 2).

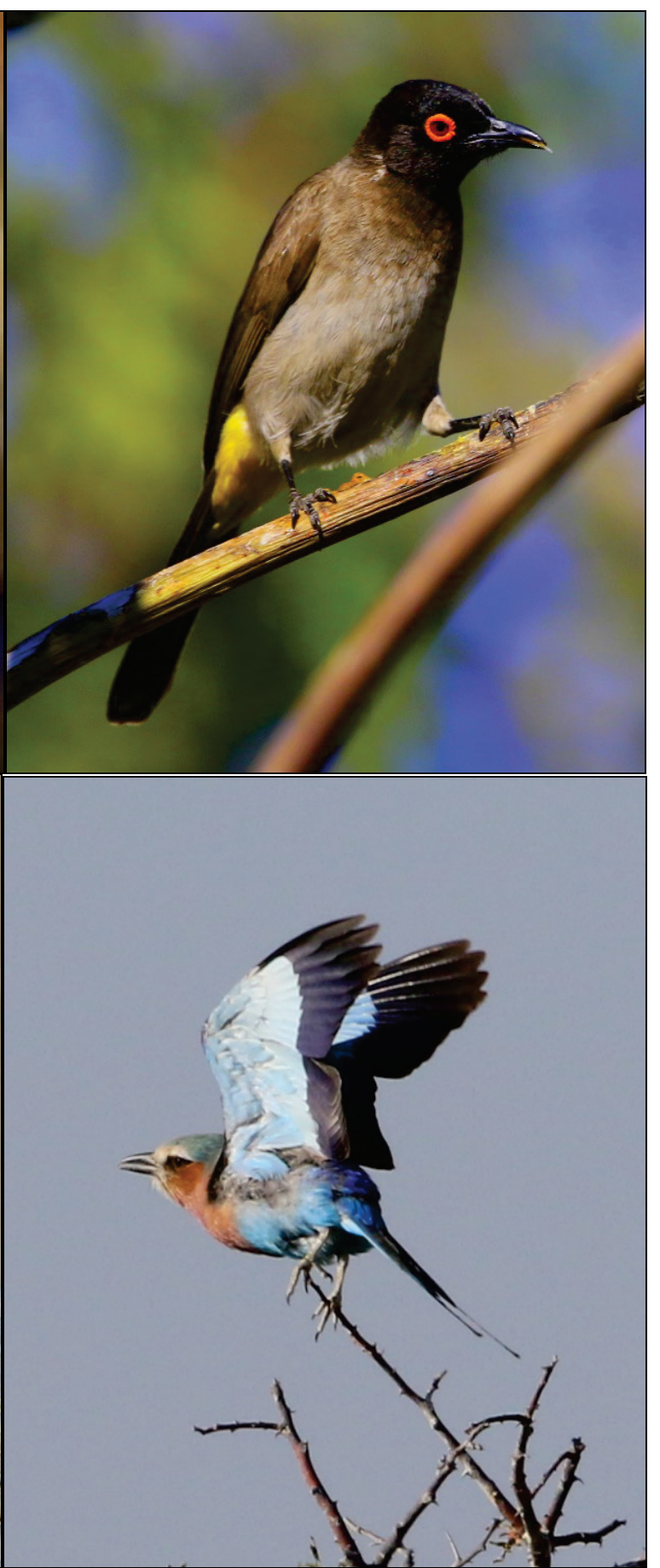

There were seven subdominant species: Rock Dove, Laughing Dove Streptopelia senegalensis, Pied Crow Corvus albus, Scaly-feathered Finch Sporopipes squamifrons, Red-headed Finch Amadina erythrocephala, Red-eyed Bulbul Pycnonotus nigricans and Red-faced Mousebird. They comprised together $20.1 \%$ of all breeding birds (Table 1 ). 
Table 1

Breeding bird community in urbanized habitats of Outapi in 2017; dominant species indicated with an asterisk

\begin{tabular}{lrrr}
\hline \multicolumn{1}{c}{ Species } & Pairs & $\begin{array}{r}\text { Pairs per } \\
100 \text { ha }\end{array}$ & $\begin{array}{c}\text { Domi- } \\
\text { nance }\end{array}$ \\
\hline House Sparrow Passer domesticus ${ }^{*}$ & 250 & 192.3 & 48.4 \\
Blue Waxbill Uraeginthus angolensis * $^{*}$ & 62 & 47.7 & 12.0 \\
African Palm Swift Cypsiurus parvis & 28 & 21.5 & 5.4 \\
Rock Dove Columba livia & 20 & 15.4 & 3.9 \\
Scaly-feathered Weaver Sporopipes squamifrons & 17 & 13.1 & 3.3 \\
Pied Crow Corvus albus & 15 & 11.5 & 2.9 \\
Red-headed Finch Amedina erythrocephala & 14 & 10.8 & 2.7 \\
Laughing Dove Streptopelia senegalensis & 13 & 10.0 & 2.5 \\
Red-eyed Bulbul Pyconotus nigricans & 13 & 10.0 & 2.5 \\
Red-faced Mousebird Urocolius indicus & 12 & 9.2 & 2.3 \\
Black-chested Prinia Prinia flavicans & 10 & 7.7 & 1.9 \\
Black-throated Canary Serinus atrogularis & 10 & 7.7 & 1.9 \\
Marico Sunbird Cinnyris mariquensis & 8 & 6.2 & 1.5 \\
African Hoopoe Upupa africana & 7 & 5.4 & 1.4 \\
African Pipit Anthus cinnamomeus & 6 & 4.6 & 1.2 \\
Southern Masked Weaver Ploceus velatus & 5 & 3.8 & 1.0 \\
Marico Flycatcher Melaenornis mariquensis & 5 & 3.8 & 1.0 \\
Black-collared Barbet Lybius torquatus & 4 & 3.1 & 0.8 \\
Lilac-breasted Roller Coracias caudatus & 3 & 2.3 & 0.6 \\
Rosy-faced Parrot Agapornis roseicollis & 3 & 2.3 & 0.6 \\
Chestnut-vented Warbler Sylvia subcaerulea & 2 & 1.5 & 0.4 \\
Village Indigobird Vidua chalybeate & 2 & 1.5 & 0.4 \\
Acacia Pied Barbet Tricholaema leucomelas & 1 & 1.2 & 0.3 \\
Little Bee-eater Merops pusilus & 1 & 0.8 & 0.2 \\
Yellow-billed Kite Milvus aegyptius & 1 & 0.8 & 0.2 \\
Southern White-faced Owl Ptilopsis granti & 1 & 0.8 & 0.2 \\
Pearl-spotted Owl Glaucidium perlatum & 1 & 0.8 & 0.2 \\
Wire-tailed Swallow Hirundo smithii & 1 & 0.8 & 0.2 \\
Mosque Swallow Cercopis senegalensis & 1 & 0.8 & 0.2 \\
\hline & & &
\end{tabular}

Table 2

The presence of large baobabs and marulas in bird territories, species strictly associated with large baobab trees are indicated with an asterisk, while bird species strictly associated with large marula trees are indicated with a cross

\begin{tabular}{|c|c|c|c|c|}
\hline Species & $\begin{array}{c}\text { Baobabs } \\
\text { present }\end{array}$ & $\begin{array}{c}\text { Baobabs } \\
\text { absent }\end{array}$ & $\begin{array}{l}\text { Marulas } \\
\text { present }\end{array}$ & $\begin{array}{c}\text { Marulas } \\
\text { absent }\end{array}$ \\
\hline Blue Waxbill & 12 & 50 & 13 & 49 \\
\hline African Palm Swift & 4 & 24 & 6 & 22 \\
\hline Scaly-feathered Weaver & 2 & 15 & 1 & 16 \\
\hline Pied Crow*+ & 6 & 11 & 5 & 10 \\
\hline Red-headed Finch & 1 & 13 & - & 14 \\
\hline Laughing Dove & 1 & 12 & 4 & 9 \\
\hline Red-eyed Bulbul*+ & 7 & 6 & 6 & 7 \\
\hline Red-faced Mousebird & 4 & 8 & 6 & 6 \\
\hline Black-chested Prinia & 2 & 8 & 3 & 7 \\
\hline Black-throated Canary* & 6 & 4 & 3 & 7 \\
\hline Marico Sunbird & 1 & 7 & 1 & 7 \\
\hline African Hoopoe* & 6 & 1 & 2 & 5 \\
\hline African Pipit & - & 6 & - & 6 \\
\hline Southern Masked Weaver & 1 & 4 & - & 5 \\
\hline Marico Flycatcher & - & 5 & - & 5 \\
\hline Black-collared Barbet*+ & 5 & - & 3 & 1 \\
\hline Lilac-breasted Roller & 1 & 2 & 2 & 1 \\
\hline Rosy-faced Parrot* & 2 & 2 & 1 & 2 \\
\hline Chestnut-vented Warbler & - & 2 & - & 2 \\
\hline Village Indigobird & - & 2 & 2 & - \\
\hline Acacia Pied Barbet+ & 1 & 1 & 2 & - \\
\hline Little Bee-eater & - & 1 & - & 1 \\
\hline Yellow-billed Kite & 1 & - & - & 1 \\
\hline Southern White-faced Owl & - & 1 & 1 & - \\
\hline Pearl-spotted Owl & 1 & - & 1 & - \\
\hline Wire-tailed Swallow & 1 & - & - & 1 \\
\hline Mosque Swallow & 1 & - & - & 1 \\
\hline
\end{tabular}
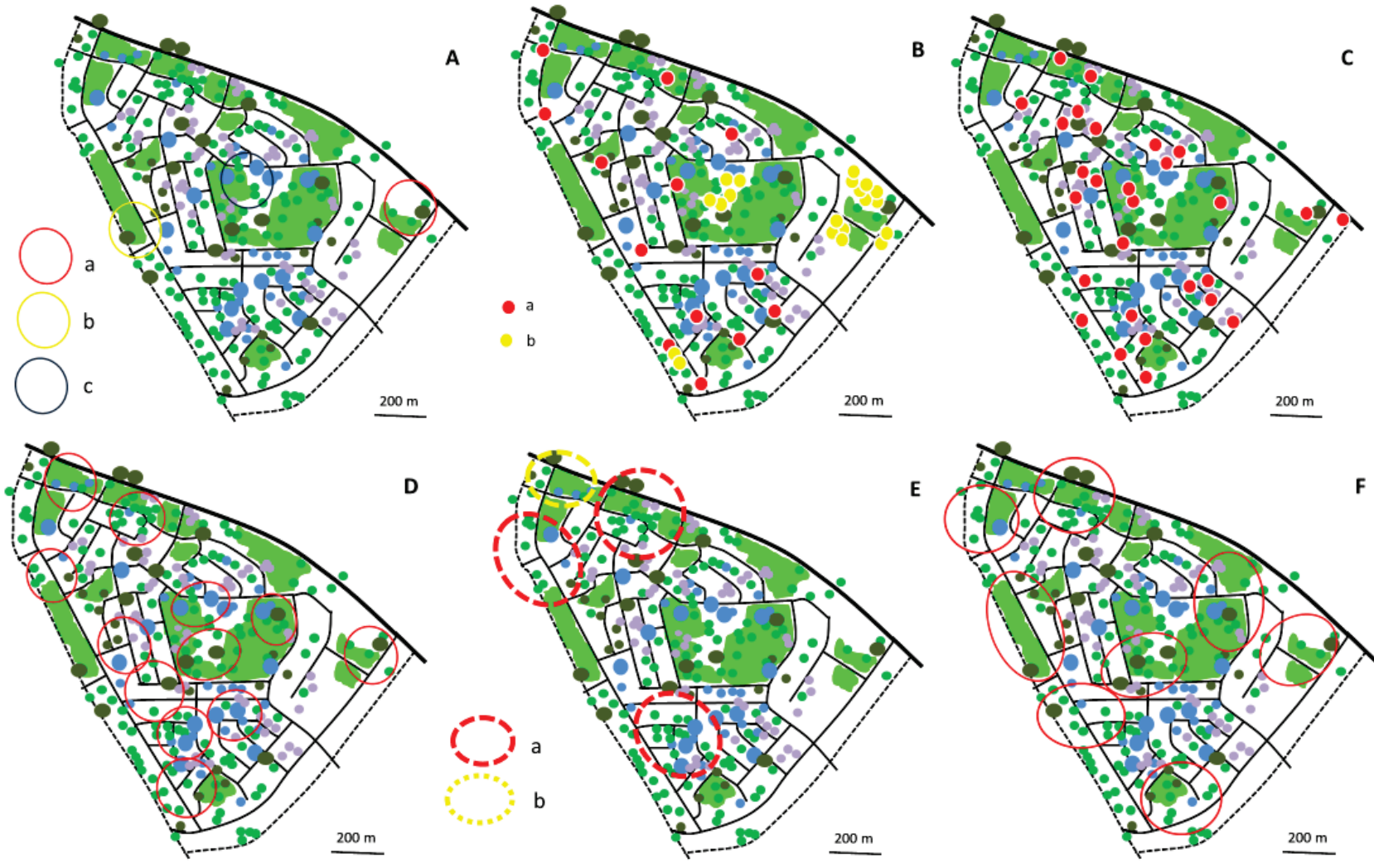

Fig. 6. Distribution of breeding pairs of bird species in Outapi in 2017: A) Yellow-billed Kite (a), White-faced Owl (b) and Pearl-spotted Owl (c); B) Laughing Dove (a), Rock Dove (b); C) African Palm Swift; D) Red-faced Mousebird; E) Lilac-breasted Roller ( $a$ ) and Little Bee-eater (b); F) African Hoopoe

Huge baobabs were located within 66 out of 251 territories of birds (all species were considered, except for the House Sparrow and Rock
Doves which are strictly associated with buildings as nesting sites). For species such as the African Hoopoe, Black-collared Barbet and Rosy- 
faced Parrot, Black-throated Canary, and Red-eyed Bulbul, more than half of their territories included huge baobabs. Huge marulas, on the other hand, were located within 62 out of 251 of those territories. About half or more than half of the Pied Crow's, Laughing Dove's, Blackcollared Barbet's, Pied Barbet's, Red-faced Mousebird's, and Red-eyed Bulbul's territories included huge marulas (Table 2).
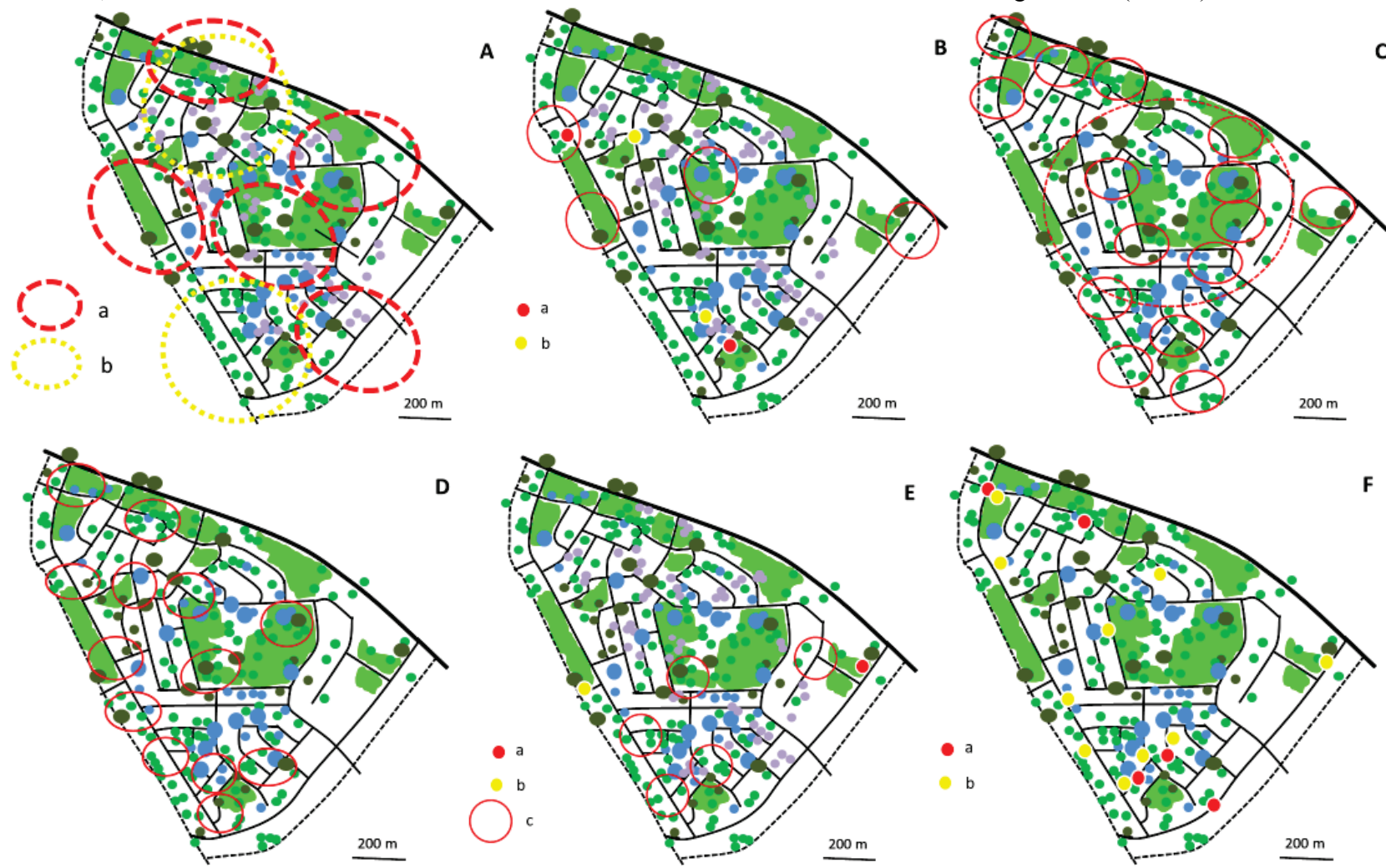

Fig. 7. Distribution of breeding pairs of bird species in Outapi in 2017: A) Black-collared Barbet $(a)$ and Acacia Pied Barbet $(b)$;

B) Rosy-faced Parrot (a), Chestnut-vented Warbler $(b)$ and Village Indigobird (c); C) Pied Crow; the large circle indicates the non-breeding grouping; D) Red-eyed Bulbul; E) Mosque Swallow (a), Wire-tailed Swallow $(b)$ and Southern Masked Weaver (c); F) Marico Flycatcher $(a)$ and Black-chested Prinia $(b)$
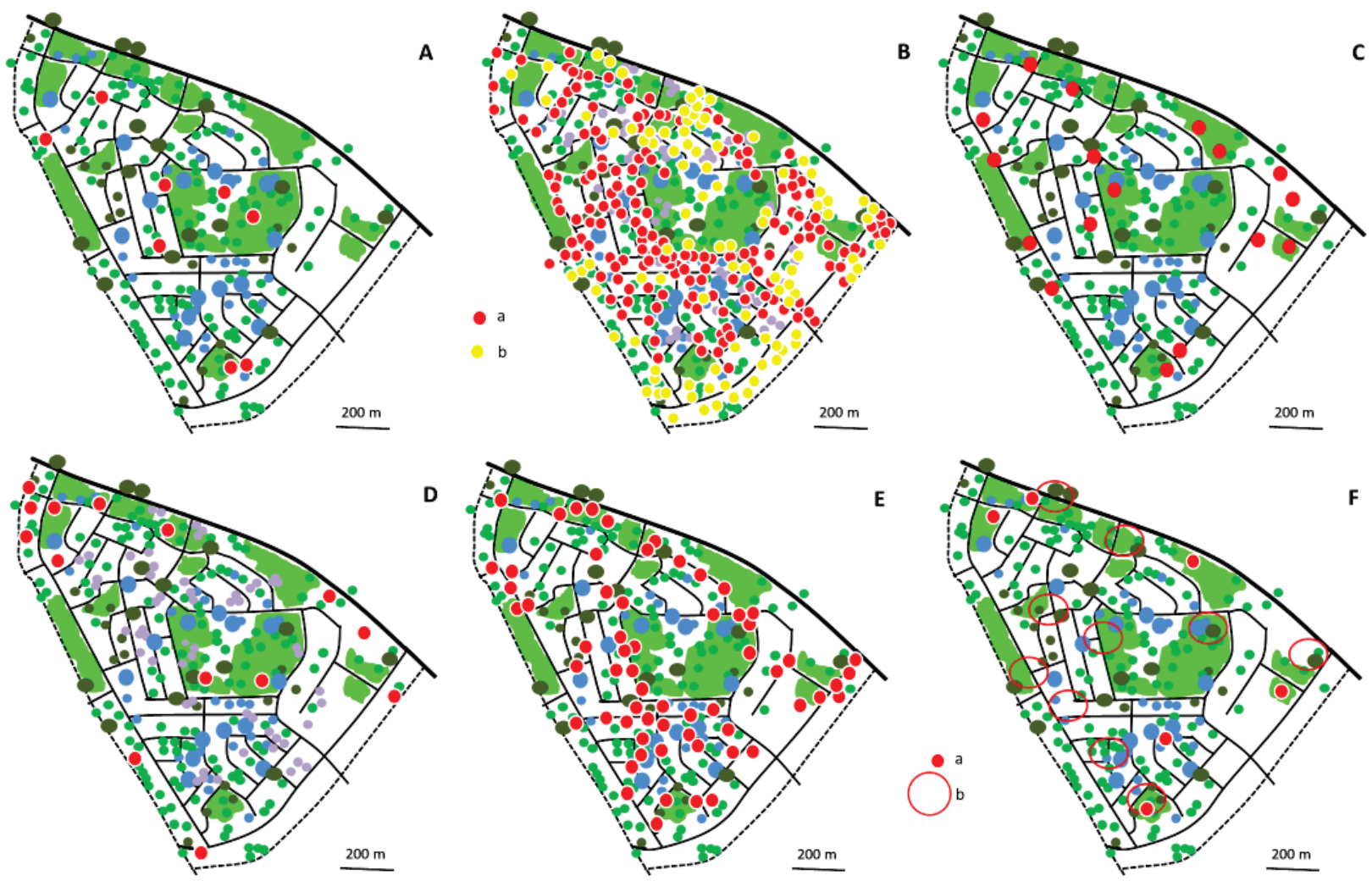

Fig. 8. Distribution of breeding pairs of bird species in Outapi in 2017: A) Marico Sunbird; B) House Sparrow ( $a$ - confirmed breeding pair, $b$ - probably breeding pair); C) Scaly-feathered Finch; D) Red-headed Finch; E) Blue Waxbill; F) African Pipit ( $a$ ) and Black-throated Canary (b) 
Table 3

Characteristics of avian assemblage in Outapi in 2017

\begin{tabular}{lc}
\hline Parameter & Value \\
\hline Number of pairs & 516.5 \\
Number of species & 29 \\
Overall density, pairs/100 ha & 397.3 \\
Cumulative dominance & 67.8 \\
Community Dominance Index & 0.60 \\
Number of dominant species & 3 \\
Simpson's Diversity Index (D) & 0.74 \\
Shannon's Diversity Index (H') & 2.13 \\
Pielou's Evenness Index (J') & 0.63 \\
\hline
\end{tabular}

Granivores were by far the most numerous feeding guild, comprising $77.2 \%$ of all birds breeding, although they were represented by nine species only. The group was dominated by the House Sparrow (48.4\%) and Blue Waxbill $(12.0 \%)$. Insectivores on the other hand, were represented by ten species, but they comprised only $11.8 \%$ of all breeding birds. Only one species of this guild, the African Palm Swift, was a dominant species, comprising 5.4\% of all breeding birds (Fig. 5).

The remaining feeding guilds comprised $11.0 \%$. Frugivores were represented by six species and comprised together $6.5 \%$. The most common of them were the Red-eyed Bulbul and Red-faced Mousebird. There was only one omnivorous species, the Pied Crow (2.6\%), one nectarivorous species, the Marico Sunbird, comprising (1.5\%), and two carnivorous species, the Yellow-billed Kite Milvus aegyptiacus (0.2\%), and Southern White-faced Owl Ptilopsis granti (0.2\%) (Fig. 5).

Birds nesting on/in buildings were represented by four species only, but they comprised the most numerous nesting guild (52.7\%). Most of them were House Sparrows. On the other hand, there were 16 species nesting on trees and/or shrubs, but they comprised only $42 \%$. Hole-nesting birds were represented by eight species, but they comprised $4.3 \%$, and birds nesting on the ground (only African Pipit Anthus cinnamonmeus) comprised the remaining $1.0 \%$. Due to a high population density of the House Sparrow, the diversity indices were low, as was also the Pielou's Evenness Index (Table 3).

\section{Discussion}

In comparison with other towns in southern Africa, where similar studies on avian communities were conducted recently, the number of breeding species in Outapi $(n=29)$ is low. In Katima Mulilo - 122 species were recorded (Kopij, 2016), Kasane - 76 (Kopij, 2018c), Bloemfontein - 51 (Kopij, 2001, 2015). Only in a town situated in the Namib Desert, Swakopmund, was the number lower (Kopij, 2018b). It was rather unexpected, as Outapi is known for its numerous huge baobabs (Munyebvu et al., 2018). Also large marula, makalani palms and other trees are fairly common there (Fig. 1). In urbanised environments in Africa, birds are attracted to large trees as a source of shelter and food (Kopij, 2000, 2001, 2015, 2016, 2018c). The town is also located in a close proximity to a canal with permanently flowing water. In Africa, close proximity of a water body may be an essential habitat prerequisite in some bird species (Hockey et al., 2005).

Also population densities of many bird species (e.g. doves from the genus Stepropelia, bulbuls from the genus Pycnonotus, Ploceus weavers) were comparatively low in Outapi (Fig. 6, 7 and 8). The Red-eyed Bulbul reached a population density of 198 pairs per 100 ha in Bloemfontein (Kopij, 2015), but only 10.0 pairs per 100 ha in Outapi (this study). The Southern Masked Weaver nested in densities ranging from 8 to 16 breeding sites per 100 ha in Bloemfontein (Kopij, 2001), while it was only 3.8 breeding sites per 100 ha in Outapi (this study). Similarly, the Red-faced Mousebird was by order of magnitude more common in Bloemfontein than it was in Outapi.

While in Blomfontein the population density of the Laughing Dove was 340 pairs per 100 ha (Kopij, 2015), it was only 10.0 pairs per 100 ha in Outapi (this study). Overall population densities of Streptopelia doves were at least five times lower in Outapi than in other southern African towns investigated so far (Table 4.). The Rock Pigeon, usually so numerous in southern African towns (Kopij, 2015), was uncommon in Outapi, while the Speckled Pigeon Columba guinea was not recorded at all. Both suitable nesting sites and food resources are commonly available for these species in the town. So low densities of doves and pigeons could have been caused by the exceptionally high population density of the Pied Crow. In addition to breeding birds, a large non-breeding grouping of the Pied Crow occupies the town throughout the year. The non-breeding grouping has been estimated at about 100-150 birds. These were probably immature birds, as Pied Crows reach sexual maturity at the age of 2-4 years (Kilham, 1989). The baobabs are their favoured roosting sites (own observ.). The Pied Crow is omnivorous, feeding often on fruits, grain products and carcasses if these are freely available (Dean, 2005). The baobabs may provide them an important food, and this merits further investigation. The baobab is a source of very nutritious flowers and fruits (Gebauer et al., 2002; Sidibe \& Williams, 2002; Leatherhead Food Research, 2009; Munyebvu et al., 2018; Staughton, 2019). A baobab powder of $100 \mathrm{~g}$ contains $250 \mathrm{kcal}$ of energy, $79.7 \mathrm{~g}$ carbohydrates, $3.7 \mathrm{~g}$ proteins, $0.5 \mathrm{~g}$ of lipids and a relatively high concentration of elements such as $\mathrm{Ca}, \mathrm{Mg}, \mathrm{Na}, \mathrm{K}, \mathrm{Fe}, \mathrm{Zn}$, and numerous vitamins (Staughton, 2019). The fruits are a source of supplementary food for people (Gebauer et al., 2002; Sidibe \& Williams, 2002; Munyebvu et al., 2018), while both the flowers and the fruits may constitute a staple food of some animal species, such as fruit bats, bulbuls, barbets and crows (own observ.). They may also be suitable nesting sites for some bird species (both hole- and tree-nesting). The Pied Crow is also known to prey on fruit bats (Dean, 2005), which commonly roost on the baobabs (own observ.). As crows are nest predators (Kilham, 1989; Dean, 2005), some bird species, especially doves (their nests are relatively easy to locate and access for the crows) may be vulnerable to high nest predation. As a result, they may breed in much lower population density than under conditions where crow population density is much lower. In most southern African towns, crows reach much lower population densities than in Outapi (Kopij, 2001, 2011, 2014a, 2015, 2016, 2018a, 2018b). Only one Streptopelia dove species, the Laughing Dove, bred in Outapi, and even so it nested in a relatively low density. The overall density of all Streptopelia doves was at least five times higher in other southern African towns (Table 4).

Table 4

Population densities of Streptopelia doves in selected southern African towns

\begin{tabular}{|c|c|c|c|c|c|c|c|}
\hline \multirow[t]{2}{*}{ Town } & \multirow{2}{*}{$\begin{array}{c}\text { Area } \\
\text { size, } \\
\text { ha }\end{array}$} & \multicolumn{5}{|c|}{$\begin{array}{l}\text { Population density, } \\
\text { pairs/100 ha }\end{array}$} & \multirow[t]{2}{*}{ Source } \\
\hline & & LD & $\mathrm{CtD}$ & ReD & $\mathrm{MD}$ & Total & \\
\hline $\begin{array}{l}\text { Bloemfontein, } \\
\text { South Africa }\end{array}$ & 5100 & 34.0 & 32.1 & 1.2 & 0.0 & 67.3 & $\begin{array}{c}\text { Kopij, } \\
2015\end{array}$ \\
\hline $\begin{array}{l}\text { Kasane, } \\
\text { Botswana }\end{array}$ & 160 & 30.0 & 18.0 & 4.0 & 4.0 & 56.0 & $\begin{array}{l}\text { Kopij, } \\
2018 b\end{array}$ \\
\hline $\begin{array}{l}\text { Katima Mulilo, } \\
\text { Namibia }\end{array}$ & 214 & 57.0 & 5.6 & 4.0 & 13.6 & 77.2 & $\begin{array}{l}\text { Kopij, } \\
\text { in press }\end{array}$ \\
\hline $\begin{array}{l}\text { Swakopmund, } \\
\text { Namibia }\end{array}$ & 415 & 47.0 & 0.0 & 0.0 & 0.0 & 47.0 & $\begin{array}{c}\text { Kopij, } \\
2018\end{array}$ \\
\hline $\begin{array}{l}\text { Walvis Bay, } \\
\text { Namibia }\end{array}$ & 260 & 59.6 & 0.0 & 0.0 & 0.0 & 59.6 & $\begin{array}{l}\text { Kopij, } \\
\text { in press }\end{array}$ \\
\hline $\begin{array}{l}\text { Outapi, } \\
\text { Namibia }\end{array}$ & 130 & 10.0 & 0.0 & 0.0 & 0.0 & 10.0 & $\begin{array}{l}\text { This } \\
\text { study }\end{array}$ \\
\hline
\end{tabular}

Note: LD - Laughing Dove S. senegalensis, Cape Turtle-Dove S. capicola, $\mathrm{ReD}$ - Red-eyed Dove $S$. semitorquata, MD - Mourning Dove $S$. decipiens.

The invasive House Sparrow has reached such a high population density in the town of Outapi that it is suspected to dislocate other bird species, especially granivores. Now, it is the only sparrow species nesting in the town. In 2011, the Grey-headed Sparrow was still recorded in Outapi as a breeding species, although in much lower numbers than the House Sparrow (Kopij, 2014a). The House Sparrow has invaded Northern Namibia (Ovamboland) in the second half of 20th century (Kopij, 2014a) and it appears that now it has almost totally displaced the indigenous Southern Grey-Headed Sparrow Passer diffusus from most urban habitats in this region. It may greatly benefit in the town from the abundance of suitable nesting sites under eaves and holes in houses. In this way it may easily avoid nest predation by the Pied Crow. The House Sparrow also has abundant food resources (food remnants based on grain left by people). Such a situation, where there is only one sparrow 
breeding in a town, is rather untypical, as 2-3 sparrow species are recorded as breeding in most other towns in southern Africa (Kopij, 2001, 2011, 2014a, 2015, 2018a; Dean, 2005).

Swallows (Hirundidae) were found to be rare breeders in the town of Outapi. It is probably due to the lack of suitable and safe nesting sites. The rare Mosque Swallow Hirundo senegalensis is associated with baobabs as nesting sites (Spottiswoode, 2005), hence its presence in the town. However, there was a lack of other swallow species relatively common in the surrounding areas, namely the Greater Striped Swallow Hirundo cucullata and Lesser Striped Swallow Hirundo abyssinica. Also among swifts (Apodidae), only the African Palm Swift was recorded as breeding in the town. Although suitable nesting sites do exist in Outapi, other swift species, especially the Little Swift Apus affinis, were not recorded in the town. However, it nested colonially under some bridges along the water canal running outside the town.

Strikingly, no Fork-tailed Drongos Dicrurus adsimils were recorded as breeding in Outapi. It is a common resident around the town and elsewhere in the Cuvelai Drainage System (Kopij, 2014b). In other towns in Namibia, e.g. in Katima Mulilo, Tsumbeb, Windhoek, it was found to be a relatively common breeding resident (Kopij, 2016, and upbubl. data). Hornbills (Tockus spp.), so widespread and common in the Cuvelai Drainage System, and in other parts of Namibia, were also not recorded as breeding residents in Outapi. They do not avoid towns and are known to breed in towns such as Tsumeb, Grootfontein, Katima Mulilo and even in the central part of Windhoek (own inf.). Shrikes (Lanidae) and bush-shrikes (Malacontidae) breed in relatively high density in Southern African towns (Kopij, 2000, 2001, 2011, 2014a, 2015, 2016, 2018a, 2018b), but in Outapi none of them was recorded. Were food resources the limiting factor for all these species, or rather were they displaced by the Pied Crow? This merits further investigation.

Further studies should also focus on year-to-year variations in the avian community in Outapi town. These variations can be linked to differential rainfall. Higher than normal rainfall may increase the species diversity, as well as population densities of some species. However, these variations may also be caused by urban development, especially related to the urban greenery, and by the attitude of citizens to nature at large and to birds specifically.

\section{Conclusion}

It appears that in urbanized areas, baobabs may attract breeding and non-breeding corvids in large numbers. They may provide them with good food in the form of sweet fruits (Gebauer et al., 2002; Sidibe \& Williams, 2002; Leatherhead Food Research, 2009; Staughton, 2019) and roosting sites. The crows, as nest predators, feed also on the eggs and nestlings of other birds. Doves seem to be especially prone to such predation, as their nests are easily to detect and destroy. As a result, they may breed in low density. This in turn, may release other dominant granivores in the towns, specifically sparrows, so that having no food competitors they may reach exceptionally high population density. They are not vulnerable to crow nest predation, as their nests are usually wellconcealed under eaves and in holes of buildings (Dean, 2005). They also display aggressive behaviour to other similar-sized granivores. The very high population density of the House Sparrow may cause declines in the population densities of other passerine bird species, especially granivores.

\section{References}

Bibby, C. J., Burgess, N. D., Hill, D. A., \& Mustoe, S. (2012). Bird census techniques. 2nd ed. Academic Press, London.

Chace, J. F., \& Walsh, J. J. (2006). Urban effects on native avifauna: A review. Landscape \& Urban Planning, 74, 46-69.

Crooks, K. R., Suarez, A. V., \& Bolger, D. T. (2004). Avian assemblages along a gradient of urbanization in a highly fragmented landscape. Biological Conservation, $115,451-562$

Dean, W. R. J. (2005). House sparrow Passer domesticus. In: Hockey, P. A. R. Dean, W. R. J., Ryan, P. G., \& Maree, S. (Eds.). Roberts' birds of Southern Africa. John Voelcker Bird Book Fund, Cape Town. Pp. 1082-1083.

Dunn, A. M., \& Weston, M. A. (2008). Review of terrestrial bird atlases of the world and their application. Emu, 108, 42-67.

Gebauer, J., El-Siddig, K., \& Ebert, G. (2002). Baobab (Adansonia digitata L.): A review on a multipurpose tree with promising future in the Sudan. Gartenbauwissenschaft, 67(4), 155-160.

Hockey, P. A. R., Dean, W. R. J., Ryan, P. G., \& Maree, S. (Eds.). (2005). Roberts' birds of Southern Africa. John Voelcker Bird Book Fund, Cape Town.

Kilham, L. (1989). The Aerican Crow and the Common Raven. College Station, Texas A. \& M. University Press.

Kopij, G. (2001). Atlas of birds of Bloemfontein. Roma. (Lesotho) / Bloemfontein (RSA): Department of Biology, National University of Lesotho, Free State Bird Club.

Kopij, G. (2011). Avian diversity in ruderal and urbanized habitats in Lesotho. Berkut, 20, 22-28.

Kopij, G. (2014a). Avian assemblages in urban habitats in North-Central Namibia. International Science and Technology Journal of Namibia, 3(1), 64-81.

Kopij, G. (2014b). Avian communities of a mixed mopane-acacia savanna in the Cuvelai Drainage System, North-Central Namibia, during the dry and wet season. Vestnik Zoologii, 48(4), 269-274.

Kopij, G. (2015). Avian diversity in an urbanized South African grassland. Zoology and Ecology, 25(2), 87-100.

Kopij, G. (2016). Birds of Katima Mulilo town, Zambezi Region, Namibia. International Science and Technology Journal of Namibia, 7, 85-102.

Kopij, G. (2018a). The role of peri-urban wetland and meadow habitats in the protection of trans-Saharan passerine species in a Central European city. Rivista Italiana di Ornitologia, 88(1), 47-52.

Kopij, G. (2018b). Provisional atlas of breeding birds of Swakopmund in the coastal Namib Desert. Lanioturdus, 51(2), 2-12.

Kopij, G. (2018c). Atlas of breeding birds of Kasane. Babbler, 64, 3-15.

Leatherhead Food Research (2009). Nutritional evaluation of baobab dried fruit pulp and its potential health benefits. PhytoTrade Africa.

Luniak, M. (2013). Kartograficzne atlasy awifauny miast w Europie - przegląd badań [Cartographic atlases on avifauna of towns in Europe - an overview pof studies]. Ornis Polonica, 54, 40-49.

Luniak, M. (2017). Urban ornithological atlases in Europe: A review. In: Murgui, E., \& Hedblom, H. (Eds.). Ecology and conservation of birds in urban environments. Springer, Heidelberg. Pp. 209-223.

Magle, S. B., Hunt, V. M., Vernon, M., \& Crooks, K. R. (2012). Urban wildlife research: Past, present, and future. Biological Conservation, 155, 23-32.

Mendelsohn, J., Jarvis, A., Roberts, C., \& Robertson, T. (2009). Atlas of Namibia. A portrait of the land and its people. Sunbird Publishers, Cape Town.

Munyebvu, F., Mapaure, I., \& Kwembeya, E. G. (2018). Abundance, structure and uses of the Baobab (Adansonia digitata L.) populations in Omusati Region, Namibia. South African Journal of Botany, 119, 112-118.

Mwinga, M., Siboleka, M., \& Kavezuva, C. (2018). Economy profile for Outapi. First Capital Treasury Solutions, Windhoek.

Sidibe, M., \& Williams, J. T. (2002). Baobab Adansonia digitata. International Centre for Underutilised Crops, Southampton.

Spottiswoode, C. N. (2005). Mosque swallow Hirundo senegalensis. In: Hockey, P. A. R., Dean, W. R. J., Ryan, P. G., \& Maree, S. (Eds.). Roberts' birds of Southern Africa. John Voelcker Bird Book Fund, Cape Town. P. 759. 